\title{
INNOVATION INFRASTRUCTURE OF UKRAINE: ASSESSMENT OF THE EFFECTIVENESS OF THE ACTION AND WAYS OF IMPROVEMENT
}

\author{
Anna Kniazevych ${ }^{1}$ \\ Rivne State University of Humanities, Ukraine \\ Volodymyr Kyrylenko² \\ Kyiv National Economic University named after V. Hetman, Ukraine \\ Ludmila Golovkova ${ }^{3}$ \\ Dnipropetrovsk National University of Railway Transport named after Academician V. Lazaryan, Ukraine
}

\begin{abstract}
The article substantiates the key role of processes of formation of an effective national innovation system, which directly provides the innovative development of the national economy of the country. The article defines peculiarities of the formation of models of national innovation systems of different countries of the world. The article develops the basic principles, on which the concept of the development of the national innovation system of Ukraine is based. One of the main factors, which directly influence the dynamics and pace of the development of the national innovation system, is the degree of the development of the country's innovation infrastructure. It should be stated that the main elements of the national innovation system of Ukraine function in isolation from each other, without any balance in this system, which causes its ineffectiveness. Further research should be aimed at establishing a systemic relationship and developing mechanisms for managing the formation and functioning of the national innovation system based on the effective innovation infrastructure of the country. At the stage of the gradual overcoming the economic crisis, the creation of favourable conditions for the fuller realization of the creative and inventive potential of the Ukrainian society is gaining a special significance in the innovative market of the country. The susceptibility of the national economy to innovation depends largely on the presence of demand for innovative products from consumers in the market, the acceleration of the dissemination of advanced technologies, including the expansion of the range of innovative active firms in the medium business, the creation of new innovative firms, and the dynamic growth of their scale. The strategy of innovation development is aimed at the formation and functioning of a specific infrastructure to increase the acceptability of the business environment to innovation. Significant activation of the market of innovations cannot be carried out without addressing, as necessary, certain markets for innovative services operating in the innovation infrastructure of the country, the economy, etc. The formation of self-sufficient and well-functioning innovative Ukrainian infrastructure, which is self-organized, is necessary not only for the harmonization of the functioning of the innovation system and national economy but also for the survival of the country. Despite the complexity and ambiguity of the influence of external and internal factors on the establishment and development of innovation infrastructure, the overall positive assessment suggests that, with certain efforts on the part of the state and business, Ukraine's innovative infrastructure can effectively develop and carry out its functions.
\end{abstract}

Key words: innovations; national innovation system; innovation infrastructure; models of national innovation systems; market of innovations.

JEL Classification: $0100,0310,0320$

\footnotetext{
Corresponding author:

${ }^{1}$ Department of Management, Rivne State University of Humanities.

E-mail: kniazevich.a@gmail.com

${ }^{2}$ Department of Political Economy, Kyiv National Economic University named after V. Hetman.

E-mail: kyrylenko.v.i@gmail.com

${ }^{3}$ Department of Finance and Economic Security, Dnipropetrovsk National University of Railway Transport

named after Academician V. Lazaryan.

E-mail: g.liudmila22@gmail.com
} 


\section{Introduction}

Globalization and the innovative way of world economy's development in the 21 st century are the decisive factors that determine and guide the further development of national economies and their national innovation systems. A key condition for accelerating social and economic development of the country, economy branches, and enterprises is the need to vigorously find and quickly implement in production the most effective innovative proposals. The creation of such conditions ensures the implementation of the innovation process, the ultimate goal of which is the introduction of priority fundamental and applied research, new, advanced technologies, forms of organization of labour and management, based on the achievements of scientific and technological progress.

The effectiveness of innovation market functioning is the main regulator of innovation development of the country and of the formation of its innovative infrastructure. The current state and prospects of the development of the innovation market determine the possibilities of a fuller use of the country's scientific, technical, and educational potential, and the revival of its innovative infrastructure. Innovation potential of the country is characterized by the willingness of the society and economy to introduce new technological and social changes under the influence of internal and external factors. The economy of the country is concerned both with the negative effects of the global financial and economic crisis and recent social and political problems. The stabilization and adaptation of the national innovation system and its innovation market in changing realities is of the highest scientific and practical significance. The effectiveness of the market mechanisms for managing innovation and the increase of the innovation activity of enterprises directly depend on the activity of supply and demand in the market of innovative products; therefore, ensuring the effective functioning of innovation infrastructure should begin with the development of the innovation market itself.

The modern business environment is becoming more and more dynamic every year, and the competition is becoming more global. The growing development of innovation activity and its transformation into a key factor of social and economic growth raises new challenges to the theory and practice of innovation management in terms of improving the concept of managing the development of national innovation systems.

The processes of the formation and functioning of the management of national innovation systems in different countries of the world have been examined in a considerable number of scientific works. Different aspects of these processes have been reflected in the research works of foreign and domestic economists, such as A. Butenko, N. Ivanova, H. Itskovits, H. Kovaliov,
Y. Lazarieva, P. Mykytiuk, L. Parashkevova, T. Skrypko, L. Fedulova, J. Christiansen, J. Schumpeter, L. Yaremko, and others.

A considerable number of scientific works have been devoted to the research of problems of formation and development of innovation infrastructure and its main component - the innovation market. These issues were actively researched in the works of such foreign scholars as I. Goriacheva, D. Dorzhiev, N. Ivanov, N. Kalenska, V. Tribushna, R. Chobanova, T. Sherstobytova, J. Schumpeter, and others. Different aspects of this issue were studied in the works of a number of Ukrainian economists, such as S. Illiashenko, M. Kanaieva, V. Soloviov, L. Fedulova, T. Shotik, I. Yanenkova, and many others.

Constant social and economic changes in the country and in the world put to scientists and business representatives a number of issues related to the need for adjustments, accounting of the dynamics of these changes and their impact on the innovation infrastructure, the specificity of the development of the domestic innovation market. The question of the composition and formation of the modern market of innovations is complex and multidimensional; therefore, despite a significant number of scientific works, it requires further research.

\section{Models of formation of national innovation systems}

National innovation systems of different countries, despite the same goal, have a number of essential features. The analysis of the existing types of national innovation systems makes it possible to distinguish between four characteristic models: the Euro-Atlantic, East Asian, alternative, and the model of the "triple helix". Each model can be regarded as a specific and characteristic for a given country mechanism for the production and industrial implementation in the form of products, goods or services.

The Euro-Atlantic model is a model of a national innovation system, the mechanism of action of which extends to all stages of the innovation cycle from the birth of an innovative idea at the levels of highly developed fundamental and applied science and to the final - the stage of production of innovative products. This model is observed and used in the most developed countries of Europe (Germany, France, Great Britain, etc.), which are the leaders in the ratings of competitiveness in the global economy.

The East Asian model is more focused on the borrowing of innovative technologies in the developed countries than on the support and development of its own fundamental science. Insufficient attention to fundamental science is compensated by the high degree of management development and the use of applied scientific and technical products, especially in the field 
of electronics and high technologies. Such a model of the national innovation system is characteristic for the countries of the East Asian region. This, above all, is Japan, as well as South Korea, Hong Kong, and Taiwan.

The alternative model of the national innovation system is used predominantly in agricultural countries that do not possess significant innovative potential in the field of fundamental and applied science and do not have rich reserves of raw materials. These countries focus on the development of agriculture, certain branches of light industry and tourism business in their innovation policies. This model includes the national innovation systems of Turkey, Thailand, Chile, Portugal, etc. The alternative model is also typical for countries that do not have sufficient financial capacity to strengthen fundamental and partly applied science, especially in the field of high technology. Such countries are looking for less costly ways of innovation development.

The model of the "triple helix" can be observed in the USA as a further stage in the development of national innovation system based on the Euro-Atlantic model and has a fundamental difference from other models not only in the structure but also in the mechanisms of interaction of the constituent elements. Today, the processes of forming such a model are beginning to appear in the developed countries of Western Europe and Japan.

The theory of "triple helix", which appeared at the beginning of the 21st century, was created by the professor of Newcastle University Henry Itskovits and the professor of Amsterdam University Loet Leydesdorff. As the scientists assume, "triple helix" best reflects the interaction and interdependence between three key institutions of the national innovation system of the country at all stages of the creation and implementation of an innovative product - the state, business, and scientific activities. These are the three branches of the genetic component of any national innovation system that evolves through a spiral moving from a lower level of the development to a higher one. The links between universities, business, and government are becoming the basis of the new model of governance, and a university, which is increasing the commercialization of its research, turns into an engine of this "triple helix". Therefore, an entrepreneurial university is the key to future development, the creation of new jobs, achievement of economic growth and stability (Itskovits, 2010).

As H. Itskovits states, "...the main difference between Russia and China is in the direction: from Russia, the advanced ideas come out to find their further development or introduction in the West, mainly in the United States. In the Chinese model, the direction is reversed - they learn everything new and promising everywhere, bring new ideas and developments to China, refine and commercialize them at home..." (Itskovits, 2010). A similar process can be observed now in Ukraine, in connection with the lack of funding of fundamental and applied science, universities cease to play the role of the "engine" of the national innovation system.

From the point of view of innovation, the theoretical and methodological basis of the national innovation system and its infrastructure is the innovative economy, intellectual property, and the intellectual economy (Butnik-Siversky, 2011). The economy is innovative if there is a developed infrastructure in the society that provides the creation of national information resources to the extent necessary to support the everaccelerating movement of scientific and technological progress and innovation development, and the society is able to produce all the necessary multi-faceted information, primarily scientific, in order to ensure dynamically stable social and economic development (Fedulova, 2009).

The national innovation system of Ukraine, due to the difficult social and political situation in the country and the lack of sufficient funding for science, can be attributed to an alternative model of the development of national innovation systems. After stabilizing the economic situation, the main task in Ukraine's modern innovation policy is to make the main emphasis in the construction of innovation infrastructure on the formation of new, entrepreneurial models of universities, which, in close cooperation with business and government, will be able to gradually, "in a helix way", raise national innovation system to a higher level of development.

\section{Innovation markets as components of the country's innovation infrastructure}

The country's exit from the crisis and economic growth are impossible without a widespread use of the achievements of science and technology and introduction into production of fundamentally new ideas, technologies, innovative products and services. Intellectual work is becoming more and more important and operates as the main factor; it is the imperative of realizing the concept of knowledge economy of postindustrial society. Knowledge-oriented economy, as the most productive power of the present day, needs to be stimulated and supported concerning both the direct producers of this driving force - scientists, researchers, and inventors of new ideas, proposals, innovation projects, and entrepreneurs who directly transform these ideas into innovations products, goods, and services.

As the results of a number of studies prove (Sherstobitova, 2009), on average for 100 successful innovations about 75 appear in response to consumer needs, and only 25 appear as a result of the introduction of new ideas that arise in the course of the scientific research and development and constructor works (SRDCW). 
The results of research and creative activity act as an intellectual product. Incorporated into an invention, discovery, scientific reports, patents, innovative projects, innovative proposals, the intellectual product becomes a commodity in the market of innovations and acts as a part of the country's innovation infrastructure.

Innovative infrastructure is considered as a dynamic self-regulatory system of markets and entities entering in these markets into certain economic relations within the limits stipulated by laws and normative and legal acts of Ukraine and providing the creation of the necessary conditions for the expanded production of innovative products, technologies, and services (Kniazevych, 2016).

The main goal of the formation and functioning of the country's innovation infrastructure is the provision of comprehensive innovation activities, preservation and development of the country's scientific and technological potential in the interests of the society, including overcoming the decline of production, its structural adjustment, changing the nomenclature of products, creating new products and new production processes.

The innovation market creates demand and defines the supply of intellectual property products. Commoditymoney relations in the market of innovations arise from the moment of fixing scientific and technical ideas, proposals, know-how, SRDCW as objects of intellectual property, patents, innovative projects, drawings, technologies, the use of which, in accordance with the current legislation, is allowed only by committing a market act of sale. As the seller in this market, the owner of the intellectual product is officially registered, and the buyer is an enterprise interested in the practical implementation of this product as an innovative product. Both the buyer and the seller act in order to obtain a certain economic effect for themselves. An aggregate of regular sales relations between manufacturers of innovative goods and their consumers determines the emergence of an innovation market.

The market of innovations, like any other market, is an economic system, in which the coordination and realization of economic interests between sellers and buyers through the mechanism of market prices take place. It refers to one of the specialized types of markets.

The conditions for the effective functioning of the market of innovations are a mechanism of competition, which is provided by a wide range of proposals of innovative ideas and projects, and the freedom to choose a partner in economic affairs; the balance of supply and demand; the creation of the developed innovationmarket infrastructure.

In addition, the specificity of the innovation market lies in the fact that the value and price of innovations on it are formed under the influence of the economic resultant interaction of factors of particular production, not only the magnitude of aggregate demand and supply
(Goriacheva, 2005). That is, the demand and supply in the market of innovations are not the main price defining factors. Everything depends on the economic factors of a particular production. This definition refers to the specifics of the innovation market exclusively.

In the market of innovative services as an integral part of the innovation infrastructure, there is a clear dependence due to peculiarities of the process of production of these services, as well as the specifics of the object of purchase.

The peculiarity of the process of manufacturing innovative services is the fact that it can be divided into two stages. The first stage is intellectual and the second is material production. Then, the consideration of innovation infrastructure as a market for innovative services implies its delineation in the processes of providing intellectual and material services.

The innovation market is the set of organizational and economic relations that arise in the process of exchanging the results of innovation activities and coordinating the interests of participants concerning prices, terms, and scales of this exchange.

Therefore, the innovation market is the set of innovative types of products and processes, legal entities and individuals who sell or purchase scientific and technical science-intensive products. As a specific sphere of sale, the market of innovations determines as the object of trade technical and socio-economic innovations, rationalization proposals, inventions, patents, technological innovations, and know-how. As a system of economic relations, it is aimed at the development, implementation, and diffusion of innovations at various levels.

At the stage of the gradual overcoming the economic crisis, the creation of favourable conditions for the fuller realization of the creative and inventive potential of the Ukrainian society is gaining a special significance in the innovative market of the country. The susceptibility of the national economy to innovation depends largely on the presence of demand for innovative products from consumers in the market, the acceleration of the dissemination of advanced technologies, including the expansion of the range of innovative active firms in the medium business, the creation of new innovative firms, and the dynamic growth of their scale.

Communication factors play a key role in the dissemination of new scientific and technical products. The high level of information exchange and close communication contribute to the rapid diffusion of innovations. Active participation in scientific and technical seminars, symposiums, exhibitions provides the acquaintance of the consumer with new products before they are brought to the market, thus forming an innovative demand. In the absence of preliminary information about a new product, the consumer can perceive its appearance on the market in the alerted way and the process of formation of demand will be too 
long, which in turn will affect the costs and financial results of the firm.

The current state of the markets for innovative services in Ukraine and the peculiarities of their further development are determined by the following factors:

1) the need to further expand the number of subjects and objects of innovation infrastructure and to increase the volume and quality of their services;

2) problems of economic development and the scarcity of state and local budgets make impossible the optimal financial support of subjects and objects of innovation infrastructure;

3) the possibility of establishing effective functioning on a commercial basis of service facilities in the structure of innovation infrastructure;

4) the formation of the innovation infrastructure is objectively conditioned by the growth of needs of subjects of innovation in the services provided and the level of the development of the national scientific and technical sphere, the availability of scientific and technical developments that can subsequently be commercialized;

5) further development of the country's innovation infrastructure is possible on the basis of processes of softening and deepening the service model of the actions of its subjects.

The model of innovation infrastructure functioning, consisting of a certain number of innovation markets, is presented in Fig. 1.

In the process of studying the real state of the markets for innovation infrastructure, we used the deterministic modelling and transformation of factor systems. One of the tasks of factor analysis is modelling the relationship between the performance indicators and factors that determine their magnitude. The results can be factorized into constituent elements (factors) in different ways and presented in the form of various types of deterministic models.

The state of markets for innovation infrastructure is influenced by both external and internal factors. To external influence, we refer the crisis state of the economy, the development of processes of technologies transfer and outsourcing, other factors of the international level. Internal factors are represented by political, economic, scientific and technical, production and financial peculiarities of the country's development (Graph 1). Let us consider in more detail their purpose and principles of the formation.

The market of intellectual property objects. In the market economy of a post-industrial society, national wealth is determined not only by the total volume of material resources of the country but also by the knowledge, values obtained in the process of intellectual work of scientists, inventors, researchers.

Intelligent labour is, without exaggeration, the highest form of human activity associated with the knowledge of the surrounding reality, which begins with the hypothesis or assumption and finishes with obtaining the result in the form of ideas, inventions, discoveries, new knowledge, etc. At the same time, receiving an innovative, useful intellectual product is probabilistic and can be both positive and negative.

The most significant and promising inventions, innovative proposals, know-how, results of intellectual work, which are officially legally registered as objects of intellectual property, become a market commodity. Intellectual property is an intangible object and intangible resource. Their author, which is a scientist, inventor, researcher, or even a whole research organization is the creator of the intellectual property object and receives the exclusive right to use it, and acts as a seller on the market of intellectual property objects. On the other hand, natural and legal persons, who wish to get the right to use these objects in their production activities, act as buyers of intellectual property objects. Mutually beneficial commercialization of intellectual products takes place in the process of selling patents, licenses and other objects of intellectual property to interested persons, direct producers of innovative products, goods, and services.

In the conditions of globalization of the world economy, the acquisition and commercial use of intellectual property objects become an important factor for the successful use of innovative ideas and the dissemination of new technologies. It facilitates the development of market-based relationships between science and production, licensing trade, technology transfer, and the formation of the market for intellectual property objects. The greatest demand is the technology of manufacturing new types of high-tech products (highly specialized technological installations, pharmaceuticals, newest technology and techniques, etc.).

On the effectiveness of the operation of the national market of intellectual property objects, one can draw conclusions on the ratio of the intellectual property represented in the sale of goods in the form of patents, licenses, innovation offers, know-how, and the number of similar goods purchased and used by producers for the production of innovative products, goods, and services.

In order to increase the level of intellectual and innovative potential of the country, it is necessary to intensify activities of the intellectual property market, to increase the prestige and payment of intellectual labour.

The market for information services. Another market in innovative infrastructure, which works in close cooperation and in parallel with the market of intellectual property, is the market for information and expert-consulting services. In this market, the information on the emergence of new scientific and innovative ideas, proposals, developments operates as a commodity; this market offers expert analysis services and the search for the most promising ideas, as well as consulting services for innovative business planning. 


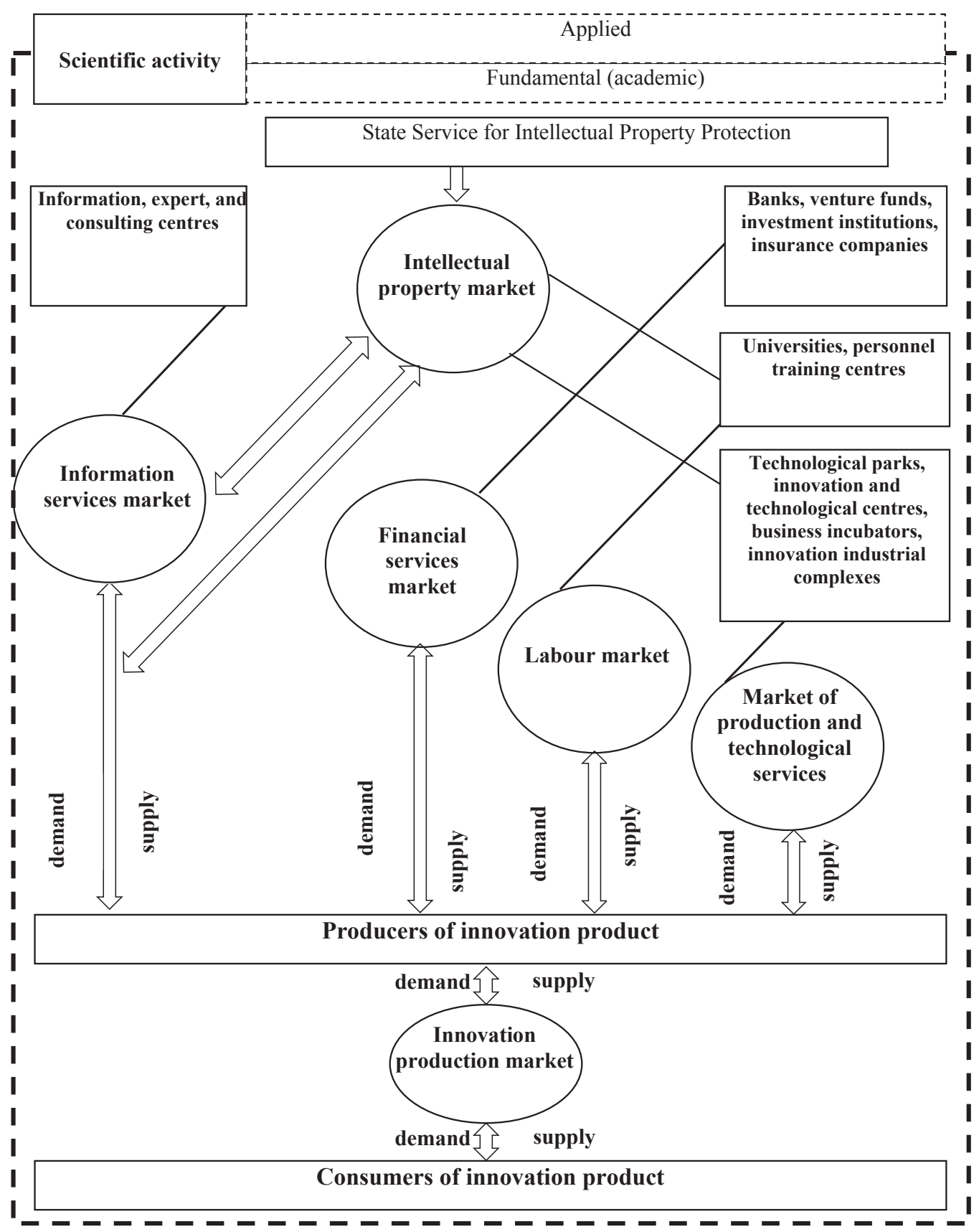

Fig. 1. The model of country's innovation infrastructure functioning

Source: the author's development

Communication in the information services market is often interactive. The structure and content of the information market products are varied and extremely changeable.

The essence of the information services market can be defined as the set of economic, legal, and social relations that arise in the process of meeting the information needs of producers who wish to set up the production of innovative products, new products, and services and are willing to pay for this information an affordable price.

The rapid growth and expansion of the demand for scientific, technical, and economic information, as well as the increased requirements for the content and forms of presentation of information, are the incentives for the development of the market of information and consulting services in the country's innovation infrastructure.

Ukraine is taking the first steps towards entering the innovative services market on the international level as an outsourcer for Western countries. So, in 2015, the rating “The 2015 Global Outsourcing 100" included four Ukrainian companies engaged in IT outsourcing: Eleks, Miratech, Softengi and SoftServe. In addition, the rating noted foreign companies, which have opened 
large offices in Ukraine: worldwide Luxoft, Belarusian Intectics, American TEAM International Services, and Softjourn. All this has a positive effect on improving the image of Ukraine on the global IT market and enhancing its information services.

The market for financial services. One of the most important problems for the country's leadership in the face of a sharp shortage of financial resources is the question of how much and what funds should be allocated for academic research, applied research and innovation. In addition, a part of public funds needs to be allocated among the subjects of innovation infrastructure to support and intensify their activities. The main receivers, for which the innovation infrastructure of the country is created, are innovative active production enterprises, which transform scientific ideas into the benefit and material goods. The current financial situation of most domestic enterprises does not allow allocating as many funds as it is necessary for the purchase of new technologies, for upgrading production equipment and training highly skilled personnel. The volume of the state budget is always limited. The difficulty in deciding on the financing of innovation production is that, above all, that in most cases such investments cannot give a quick return. In addition, investing in research and development, and the organization of innovation production always serve as long-term, strategic decisions that have to be taken considering the overall innovation policy of the state.

The mandatory part of state financing of the subjects of innovation infrastructure includes, first of all, financing of the development of fundamental (academic) science.

The costs of applied scientific and technical research and design work, research and experimental development, technology and production and technical development of the production of new products can be financed both at the expense of the state budget and at the expense of other sources. Such sources of funding may become:

- bank and innovation credits;

- the issue of securities;

- the use of venture capital;

- self-financing;

- financing of an innovative project from the income received in the process of implementing short-term projects;

- leasing of temporarily free assets;

- provision of the property of the enterprise on the security of received funds;

- sale of licenses for the use of innovative technologies and know-how;

- outsourcing in innovation activity as a method of attracting foreign investment;

- state incentives, the creation of privileged conditions for external and internal investment in innovation and new technologies.
The expansion and maximum possible use of all potential sources of financing is a priority task for the development of the financial services market.

The labour market in the structure of innovation infrastructure acts as the regulator of social and economic and labour relations between the state, the employer, and employees on the issues of hiring, use, training and retraining, and the improvement of skills of the workforce in the process of innovation production. Innovations in modern technology and systematic updating of manufactured products raise the requirements to the quality of labour resources training and cause the need for continuous training and retraining of personnel. In many regions of the country, there is a shortage of highly skilled specialists, especially managers who have the experience in innovation entrepreneurship.

The labour market is entirely dependent on the state of the national economy and the level of unemployment. In 2005-2007, Ukraine's economy was growing, specialists were in deficit, and they dictated their employment conditions to the employers. The state of the labour market has changed dramatically because of recent social, political, and military events in Ukraine. The number of vacancies has decreased by almost $20 \%$; the number of migrant workers (internally displaced) in the country is increasing constantly and the unemployment is rising.

The outsourcing of HR services from large international companies can be promising for the national innovation system, as it will contribute to the harmonization of the labour market and social interests of Ukrainian society.

The market for manufacturing and technological services includes services and opportunities provided by innovative enterprises, technological parks, innovation technology centres, innovation and industrial complexes, as well as the centres for the transfer of technologies, centres for the collective use of high-tech equipment. The need to create a market for industrial and technological services in the field of innovation production is determined by the needs of enterprises in obtaining technical and technological assistance, in providing them with production space and equipment necessary for the successful implementation of innovative projects. Accompanying support may also be related to the preliminary preparation of material resources, the implementation of resource and energysaving technologies, the provision of innovative products of complete market readiness.

In Ukraine, over the past decades, there has been a decline in industrial production. The fall of industrial production and especially of high-tech manufacturing industries leads to the degradation and destruction of the national economy and gradual de-industrialization of the national economy. The main production facilities are worn out by $50-60 \%$; new equipment is not installed 
due to insufficient funding. Acquiring new technologies and improving the quality of products are very slow, which adversely affects the competitiveness of goods in the world market.

One of the ways to solve the problems of the manufacturing and technology sector can be the creation of outsourcing companies with large foreign manufacturers of innovative products. Outsourcing of production space, equipment, technology, and labour is widely used in many countries around the world. In modern conditions, it is a universally recognized and one of the most effective methods for the development of innovative entrepreneurial activity.

For Ukraine, outsourcing from leading global companies is an opportunity to attract foreign investors. Ukraine can become a wonderful platform for the construction of buildings and production facilities of foreign corporations, which produce cars, electronic high-tech equipment and devices. All this, ultimately, will open up wide opportunities for restructuring and innovation of the national industry.

The market for ready-made innovative products. The low demand for ready-made innovative products inside and outside the country is the main reason for the weak development of the market for innovative products. This is due to the low solvency of enterprises where this product could be used, as well as the lack of information, the lack of advertising about the opportunities and quality of new products, the lack of promoting innovative products in the markets.

Of great importance for solving this problem is the optimization of the combination of a market mechanism with state regulation. State regulation of the market for innovative products can be carried out with both direct and indirect methods, which include economic, informational, legislative, and administrative components.

\section{Factor model for assessing the effectiveness of innovation infrastructure of Ukraine}

The factor model of the estimation of the external and internal environment and the degree of its influence on the formation of the innovation infrastructure in Ukraine is the matrix of evaluation criteria, which indicates the actual state of the research object (Table 1).

Table 1

Factor model for assessing the external and internal environment and the degree of their influence on the formation of innovation infrastructure in Ukraine

\begin{tabular}{|c|c|c|c|c|c|c|c|c|}
\hline \multirow[b]{2}{*}{ № } & \multirow[b]{2}{*}{$\begin{array}{c}\text { Factors and the degree of their positive or } \\
\text { negative influence: } \\
0 \text {-no influence; } \\
1 \text { - weak influence; } \\
2 \text { - medium influence; } \\
3 \text { - strong influence. }\end{array}$} & \multicolumn{6}{|c|}{ Innovation infrastructure markets } & \multirow[b]{2}{*}{$\begin{array}{l}\text { The total actual } \\
\text { (maximum } \\
\text { possible) } \\
\text { estimate of the } \\
\text { impact of each } \\
\text { of the operating } \\
\text { factors in grades }\end{array}$} \\
\hline & & 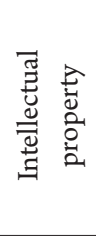 & 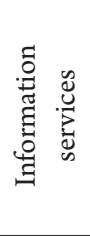 & 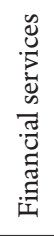 & $\begin{array}{l}\vec{\Xi} \\
\text { Оे } \\
\text { О्ञ }\end{array}$ & 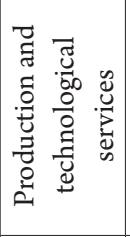 & 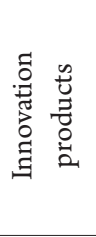 & \\
\hline & External factors & & & & & & & \\
\hline 1. & Crisis condition of the world economy & 0 & -1 & -2 & +2 & +1 & -2 & -2 \\
\hline 2. & Tensions in international relations & 0 & 0 & -1 & +1 & 0 & -1 & -1 \\
\hline 3. & $\begin{array}{l}\text { International transfer of technologies and } \\
\text { outsourcing }\end{array}$ & +2 & +3 & +3 & +2 & +3 & +2 & +15 \\
\hline \multirow[t]{2}{*}{4.} & Membership in the European Union and WTO & +1 & +3 & +3 & +2 & +2 & +3 & +14 \\
\hline & Internal factors & & & & & & & \\
\hline 5. & Unstable social and political situation & -2 & -2 & -3 & -2 & -2 & -3 & -14 \\
\hline 6. & Modern condition of the economy & -1 & -2 & -3 & -1 & -2 & -2 & -11 \\
\hline 7. & State innovation policy & +3 & +2 & +2 & +2 & +3 & +2 & +14 \\
\hline 8. & Provision of state financing & +1 & 0 & +1 & +1 & 0 & 0 & +3 \\
\hline 9. & $\begin{array}{l}\text { Scientific and technological potential of the } \\
\text { country }\end{array}$ & +3 & +2 & +1 & +1 & +2 & +2 & +11 \\
\hline 10. & Education and training of personnel & +3 & +2 & 0 & +3 & +2 & +2 & +12 \\
\hline 11. & Availability of material resources & 0 & +1 & +1 & 0 & +2 & +3 & +7 \\
\hline 12. & Availability of fuel and energy resources & -1 & -2 & -2 & 0 & -2 & -2 & -9 \\
\hline 13. & $\begin{array}{l}\text { Modern condition of equipment and } \\
\text { technologies }\end{array}$ & -2 & -2 & 0 & -1 & -2 & -3 & -10 \\
\hline 14. & Innovation potential of entrepreneurship & 0 & +1 & +1 & +1 & +1 & +1 & +5 \\
\hline 15. & The attitude of the society to the innovations & +1 & +1 & 0 & +1 & +1 & 0 & +4 \\
\hline \multicolumn{2}{|r|}{$\begin{array}{l}\text { Aggregate evaluation of all influencing factors on } \\
\text { each innovation infrastructure market in grades }\end{array}$} & +8 & +6 & +1 & +12 & +9 & +2 & $+38(+270)$ \\
\hline
\end{tabular}

Source: the author's development 
It takes into account the weight and assessment of the current state of Ukraine's innovation infrastructure. The results are based on expert judgment. As a result of the study of the environment for the formation of innovation infrastructure, we have received the assessment of the actual state of each of the operating factors - 38 points out of 270 possible, which is $14.08 \%$ of the maximum value.

Determining the factors that influence the efficiency of the Ukrainian innovation infrastructure has allowed us to form a system of criteria and indicators for conducting correlation-regression analysis. We have systematized these indicators based on the principle of complex characteristics of all components of the innovation market as a part of the innovation infrastructure of the country (Tables 2 ). The statistical data was systematized according to the selected groups; correlation-regression analysis was carried out, and correlation coefficients were calculated - paired and general. The calculation of correlation indicators was carried out using the analytical package Microsoft Excel (Kniazevych, 2016).
Among the obtained indicators, we conduct the selection based on the principle of the highest correlation with the result indicator - the volume of the implemented innovative products and a minimum correlation with each other. The most important results of the assessment of the factors of the country's innovation infrastructure are: $N_{5}$ - the number of executed scientific and technical researches; $I_{2}$ - the number of the received security documents on the results of fundamental research; $I_{3}$ - the number of the received security documents on the results of applied research; $K_{1}$ - the capacity of the consulting services market; $F_{1}$ - total amount of innovation activity financing; $G_{1}$ - the number of enterprises that were mastering the production of the innovative types of products.

With the selected indicators (Table 2), we perform regression analysis and determine coefficients of the equation (formula 1 ).

$$
\begin{aligned}
& y=1,957636 \cdot x_{1}+60,48499 \cdot x_{2}-26,1292 \cdot x_{3}+0 \cdot x_{4}- \\
& -0,23786 \cdot x_{5}+0 \cdot x_{6}=, 957636 \cdot x_{1}+60,48499 \cdot x_{2}- \\
& -26,1292 \cdot x_{3}-0,23786 \cdot x_{5},
\end{aligned}
$$

Table 2

\begin{tabular}{|c|c|c|c|c|c|c|}
\hline \multirow{2}{*}{ Indicators } & \multirow{2}{*}{ Symbols } & \multicolumn{5}{|c|}{ Years } \\
\hline & & 2010 & 2011 & 2012 & 2013 & 2014 \\
\hline The volume of the realized innovation product, million UAH & $\mathrm{Y}$ & 33697,6 & 42386,7 & 36157,7 & 35891,6 & 25669,0 \\
\hline \multicolumn{7}{|c|}{ The market for innovative scientific and technical proposals, concepts (SRDCW) } \\
\hline $\begin{array}{l}\text { Number of organizations carrying out scientific and technical } \\
\text { activity, units }\end{array}$ & $\mathrm{N}_{1}$ & 1303 & 1255 & 1208 & 1143 & 999 \\
\hline $\begin{array}{l}\text { Number of employees of the organizations that carry out scientific } \\
\text { and technical activities, thousand people }\end{array}$ & $\mathrm{N}_{2}$ & 141,1 & 134,7 & 129,9 & 123,2 & 109,6 \\
\hline Financing of the scientific sphere, million UAH & $\mathrm{N}_{3}$ & 4640,57 & 5126,81 & 6126,87 & 5962,16 & 5278,52 \\
\hline $\begin{array}{l}\text { Budget financing of research and development activities, million } \\
\text { UAH }\end{array}$ & $\mathrm{N}_{4}$ & 4223,05 & 4594,07 & 5450,56 & 5347,79 & 4728,91 \\
\hline Number of executed scientific and technical researches, thousand units & $\mathrm{N}_{5}$ & 52,0 & 52,3 & 52,3 & 47,9 & 43,0 \\
\hline Budget financing of fundamental research, million UAH & $\mathrm{N}_{6}$ & 2403,80 & 2564,03 & 3020,84 & 3023,83 & 2795,13 \\
\hline Budget financing of applied research, million UAH & $\mathrm{N}_{7}$ & 1595,62 & 1746,40 & 2126,37 & 2065,82 & 1823,69 \\
\hline \multicolumn{7}{|c|}{ Intellectual property market } \\
\hline Number of received security documents for inventions, units & $\mathrm{I}_{1}$ & 1991 & 2703 & 2743 & 2786 & 2270 \\
\hline $\begin{array}{l}\text { Number of received security documents based on the results of } \\
\text { fundamental research, units }\end{array}$ & $\mathrm{I}_{2}$ & 1280 & 1948 & 2220 & 1715 & 1721 \\
\hline $\begin{array}{l}\text { Number of received security documents based on the results of } \\
\text { applied research, units }\end{array}$ & $\mathrm{I}_{3}$ & 2546 & 3725 & 4619 & 3148 & 3203 \\
\hline \multicolumn{7}{|c|}{ Information services market } \\
\hline Capacity of the consulting services market, million USD & $\mathrm{K}_{1}$ & 300 & 337 & 392 & 445 & 490 \\
\hline \multicolumn{7}{|c|}{ Financial services market } \\
\hline Total amount of innovation activity financing, million UAH & $\mathrm{F}_{1}$ & 8045,5 & 14334 & 11481 & 9562,6 & 7695,9 \\
\hline \multicolumn{7}{|c|}{ The market for ready innovation product } \\
\hline $\begin{array}{l}\text { Number of enterprises that were mastering the production of } \\
\text { innovative products, units }\end{array}$ & $\mathrm{G}_{1}$ & 615 & 731 & 704 & 683 & 600 \\
\hline $\begin{array}{l}\text { Number of new technologies, which were bought by industrial } \\
\text { enterprises, units }\end{array}$ & $\mathrm{G}_{2}$ & 707 & 872 & 739 & 651 & 543 \\
\hline Innovation production, number of positions & $\mathrm{G}_{3}$ & 2408 & 3238 & 3403 & 3138 & 3661 \\
\hline Total amount of innovation expenses in industry, million UAH & $\mathrm{G}_{4}$ & 8045,5 & 14333,9 & 11480,6 & 9562,6 & 7695,9 \\
\hline
\end{tabular}

The system of indicators for finding the dependence of the volume of realized innovative products on the efficiency of innovation market functioning within the innovation infrastructure of Ukraine

Source: developed by the author based on statistic data (The state of science and technology, the results of scientific, technical, innovation activity, technology transfer in 2014, 2015) 
$y$ - the volume of the realized innovative products, million UAH;

$x_{1}$ - the number of executed scientific and technical researches, thousand units;

$x_{2}$ - the number of the received security documents on the results of fundamental research, units;

$x_{3}$ - the number of the received security documents on the results of applied research, units;

$x_{4}$ - the capacity of the consulting services market, million USD;

$x_{5}$ - the total amount of innovation activity financing, million UAH;

$x_{6}$ - the number of enterprises that were mastering the production of the innovative types of products, units.

Values of the number of the received security documents based on the results of the fundamental research have the highest level of influence on the resulting indicator. That is, with an increase in the number of the received security documents based on the results of fundamental researches by one unit, the volume of the realized innovative products will increase on average by 60.485 million UAH. With an increase in the number of the received security documents on the results of applied research by one unit, the volume of the realized innovative products increases by 1.958 million UAH. The constructed model provides an opportunity to predict the state of innovation infrastructure in the future, for this, it is necessary to identify trends in its factors development.

The system of indicators for finding the dependence of the volume of the realized innovative products on the efficiency of innovation market functioning within the innovation infrastructure of Ukraine is formed.

\section{Conclusion}

One of the main factors, which directly influence the dynamics and pace of the development of the national innovation system, is the degree of the development of the country's innovation infrastructure. It should be stated that the main elements of the national innovation system of Ukraine function in isolation from each other, without any balance in this system, which causes its ineffectiveness. Further research should be aimed at establishing a systemic relationship and developing mechanisms for managing the formation and functioning of the national innovation system based on the effective innovation infrastructure of the country.

At the stage of the gradual overcoming the economic crisis, the creation of favourable conditions for the fuller realization of the creative and inventive potential of the Ukrainian society is gaining special significance in the innovative market of the country. The susceptibility of the national economy to innovation depends largely on the presence of demand for innovative products from consumers in the market, the acceleration of the dissemination of advanced technologies, including the expansion of the range of innovative active firms in the medium business, the creation of new innovative firms, and the dynamic growth of their scale.

The strategy of innovation development is aimed at the formation and functioning of a specific infrastructure to increase the acceptability of the business environment to innovation. Significant activation of the market of innovations cannot be carried out without addressing, as necessary, certain markets for innovative services operating in the innovation infrastructure of the country, the economy, etc.

The formation of self-sufficient and well-functioning innovative Ukrainian infrastructure, which is selforganized, is necessary not only for the harmonization of the functioning of the innovation system and national economy but also for the survival of the country. Despite the complexity and ambiguity of the influence of external and internal factors on the establishment and development of innovation infrastructure, the overall positive assessment suggests that, with certain efforts on the part of the state and business, Ukraine's innovative infrastructure can effectively develop and carry out its functions.

\section{References:}

Butenko, A. \& Lazarieva, Y. (2008). Infrastructure components of an innovative economy model. Economics and Forecasting, 4, 69-82 (in Ukr.).

Christiansen, J. A. (2000). Building the innovative organization: Management systems that encourage innovation. New York: St. Martin's Press (in Bulgarian).

Chobanova, R. (2012). Innovativeness of the national economy. Sofia: Academic publishing house «Prof. Marin Drinov» (in Bulgarian).

Dorzhieva, D.D. (2009). Innovative Infrastructure as a Factor of Socio-Economic Development of the Region. Extended abstract of candidate's thesis. Ulan-Ude: East Siberian State Technological University (in Russ.).

Fedulova, L.I. (2009). Knowledge economy. Kyiv: Institute for Economics and Forecasting, Ukrainian National Academy of Sciences (in Ukr.).

Fedulova, L.I. (2016). Innovativeness of the economies of the EU and Ukraine: undertakings to narrow the gap. Economic Annals-XXI, №156(1-2), 22-25. (in Ukr.) doi: http://dx.doi.org/10.21003/ea.V156-0005

Goriacheva, I.A. (2005). Features of the market of scientific and technical production. Tatishchev reading: actual problems of science and practice: Proceeding of the International Scientific Conference. (Vols. 2), (pp. 180-183). Tolyatti (in Russ.). 
Illiashenko, S.M. (2003). Management innovative development: problems, concepts methods. Sumy : University book (in Ukr.).

Innovative infrastructure in the context of the national innovation system (economic and legal problems). Ed. by Butnik-Siversky, O. (2011). Kyiv: Lazuryt-Polihraf (in Ukr.).

Itskovits, H. (2010). Triple spiral: universities - enterprises - state. Innovation in action. Tomsk: Tomsk State University of Control Systems and Radioelectronics (in Russ.).

Ivanova, N.I. (2002). National Innovation Systems. Moscow: Nauka (in Russ.).

Kalenska, N.V. (2010). Methodology of Formation of Infrastructural Maintenance of Innovative Development of Industrial Enterprises. Extended abstract of Doctor's thesis. Kazan, Kazan State Technological University (in Russ.).

Kanaieva, M. (2008). Classification of components and elements of innovation infrastructure. Bulletin of Taras Shevchenko National University of Kyiv. Economics, 99, 35-39 (in Ukr.).

Kniazevych, A. (2016). Formation and functioning of innovation infrastructure in Ukraine. Rivne: Volinski oberegi (in Russ.).

Kniazevych, A. (2016). Management of formation and functioning of innovative infrastructure of Ukraine. Extended abstract of Doctor's thesis. Varna: Varna Free University „Chernorizets Hrabar” (in Bulgarian).

Kovaliov, H. (1999). Fundamentals of Innovation Management. Moscow: YUNITI (in Russ.).

Kyrylenko, V. (2014). Formation of the "knowledge economy" in the context of economic growth. European vector of economic development, №2(17), 96-101 (in Ukr.).

Law of Ukraine on innovative activity from July 4, 2002 № 40-IV. (2002). Bulletin of Verkhovna Rada of Ukraine. No. 36, pp. 266 (in Ukr.).

Mykytiuk, P. (2006). Innovation management. Ternopil: Ekonomichna dumka (in Ukr.).

On Approval of the Concept for the Development of the National Innovation System: Order of the Cabinet of Ministers of Ukraine from June 17, 2009 №. 680-p. (2009). Retrieved from: http://zakon4.rada.gov.ua/laws/ show/680-2009-p. (in Ukr.).

Sherstobitova, T.I. (2009). Marketing of innovation. Penza: PSU (in Russ.).

Schumpeter, J.A. (2007). Theory of Economic Development. Moscow: JeKSMO (in Russ.).

Shotik, T.M. (2010). The innovation infrastructure of the world. Bulletin of the National University "Lviv Polytechnic". Logistics, 699, 327-334 (in Ukr.).

Skrypko, T. (2011). Innovation management. Kyiv: Znannia (in Ukr.).

Soloviov, V.P. (2006). Innovation Activity as a System Process in a Competitive Economy (Synergistic Effects of Innovation). Kyiv: Feniks (in Russ.).

The state of science and technology, the results of scientific, technical, innovation activity, technology transfer in 2014, 2015. Kyiv, Ministry of Education and Science of Ukraine, Ukrainian Institute of Scientific, Technical and Economic Information (in Ukr.).

Tribushna, V.H. (2011). Innovative infrastructure as the necessity of support high technology entrepreneurship: technology parks and strategic management. Izhevsk: Izhevsk State Technical University (in Russ.).

Yanenkova, I.H. (2012). Organizational and managerial resources of innovation development of economy: Methodology and Practice. Mykolayiv: ChDU im. P.Mohyly (in Ukr.).

Yaremko, L. (2007). National innovation system and its formation in Ukraine. Formation of market relations in Ukraine, 1, 54-57 (in Ukr.).

Zhylinska, O. \& Firsova, S. (2015). Outlay for commercialization of high-tech products in the context of marketing models of innovation diffusion. Bulletin of Taras Shevchenko National University of Kyiv. Economics, 7 (172), 6-13 (in Ukr.) doi: http://dx.doi.org/10.17721/1728-2667.2015/172-7/1. 